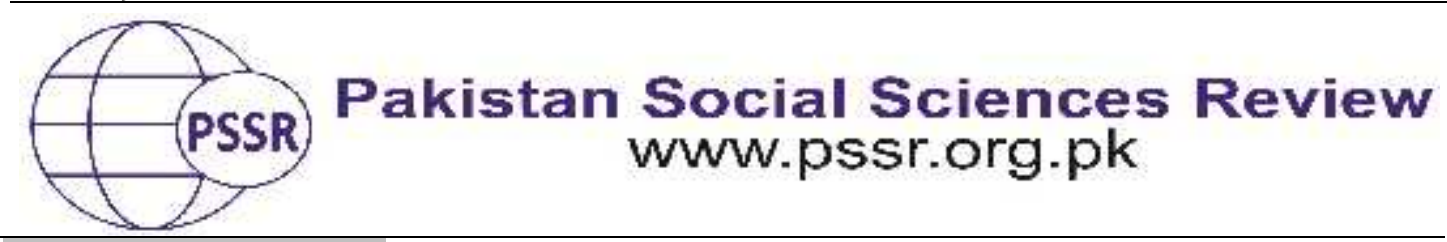

RESEARCH PAPER

\title{
Estimating the Optimum Level of Debt-Threshold: Empirical Evidence from Pakistan
}

\author{
Minhaj-ud-Din ${ }^{* 1}$ Muhammad Azam Khan² Muhammad Tariq ${ }^{3}$
}

1. Department of Economics, Faculty of Business and Economics, Abdul Wali Khan University Mardan, KP-Pakistan

2. Department of Economics, Faculty of Business and Economics, Abdul Wali Khan University Mardan, KP-Pakistan

3. Department of Economics, Faculty of Business and Economics, Abdul Wali Khan University Mardan, KP-Pakistan

\begin{tabular}{|c|c|}
\hline PAPER INFO & ABSTRACT \\
\hline $\begin{array}{l}\text { Received: } \\
\text { March 21, } 2021 \\
\text { Accepted: } \\
\text { June 20, } 2021 \\
\text { Online: } \\
\text { June 25, } 2021\end{array}$ & $\begin{array}{l}\text { This study aims to determine the debt threshold of foreign debt } \\
\text { and investigate the effectiveness of debt overhang effect beyond } \\
\text { this threshold. ARDL model is framed within the structure of } \\
\text { Solow growth model for estimating the coefficients of this } \\
\text { model. Quadratic bivariate model is applied to determine the } \\
\text { optimum level of debt-threshold Different sort of diagnostic }\end{array}$ \\
\hline $\begin{array}{l}\text { Keywords: } \\
\text { ARDL, } \\
\text { Debt Threshold, } \\
\text { Debt-Laffer } \\
\text { Curve, } \\
\text { Economic Growth, } \\
\text { External Debt, } \\
\text { Pakistan } \\
\end{array}$ & $\begin{array}{l}\text { tests are also conducted in this study. Sample period is ranging } \\
\text { from } 1976-2020 \text {. This study finds that debt overhang is effective } \\
\text { above the optimal level of foreign debt which is } 26.4 \% \text { of gross } \\
\text { domestic product. Findings also depict that Pakistan is } \\
\text { experiencing the debt-overhang effect since } 1976 \text { as the ratio of } \\
\text { external debt-to-GDP has remained over and above the optimal } \\
\text { level of debt across the sample. Since no government can avoid }\end{array}$ \\
\hline $\begin{array}{l}\text { *Corresponding } \\
\text { Author }\end{array}$ & $\begin{array}{l}\text { external borrowing completely, therefore this study } \\
\text { recommends that government borrowing should be restricted to } \\
\text { the optimum level of foreign debt. Similarly, efforts should also } \\
\text { be made for downsizing the debt burden by utilizing the non- } \\
\text { debt sources of finances like grants and revenues and that } \\
\text { effective debt-management policies should be formulated for } \\
\text { enhancing the economic productivity. }\end{array}$ \\
\hline
\end{tabular}

\section{Introduction}

External debt is not only accumulated for the purpose of filling the gap created by twin deficits but also for retaining the economies at optimal level of economic growth (Omotosho et al., 2016). Governments also need external financing when they suffer from severe financial crunch and that internal resources are not sufficient for the fulfillment of financial needs. Most of the least developed countries are engaged in external borrowing for meeting with their financial goals and completing their developmental projects, whereas advanced countries do so for 
making their economies progressive (Nwankwo, 2014). However, if countries fail to inject such finances in productive channels, then excessive borrowing will lead to destruct the overall repayment mechanism of loan amortization and, in the long run, such countries will face the vicious-cycle of debt (Minhaj-ud-Din, Azam \& Tariq, 2020). Researchers also believe that external finances help in improving the macroeconomic parameters upto the debt-threshold beyond which a slight increase in debt is considered inimical and curse for growth and prosperity (Ogunmuyiwa, 2011). This relationship can be expressed with the help of Debt-Laffer curve which represents the growth-maximizing debt-to-GDP ratio or the turning point of external debt. This turning point of debt is also known by debt inflexion point or debt tipping point. Figure 1 is the hypothetical presentation of the Debt-Laffer curve.

Figure 1: $\quad$ Debt-Laffer-

GDP Growth

Curve

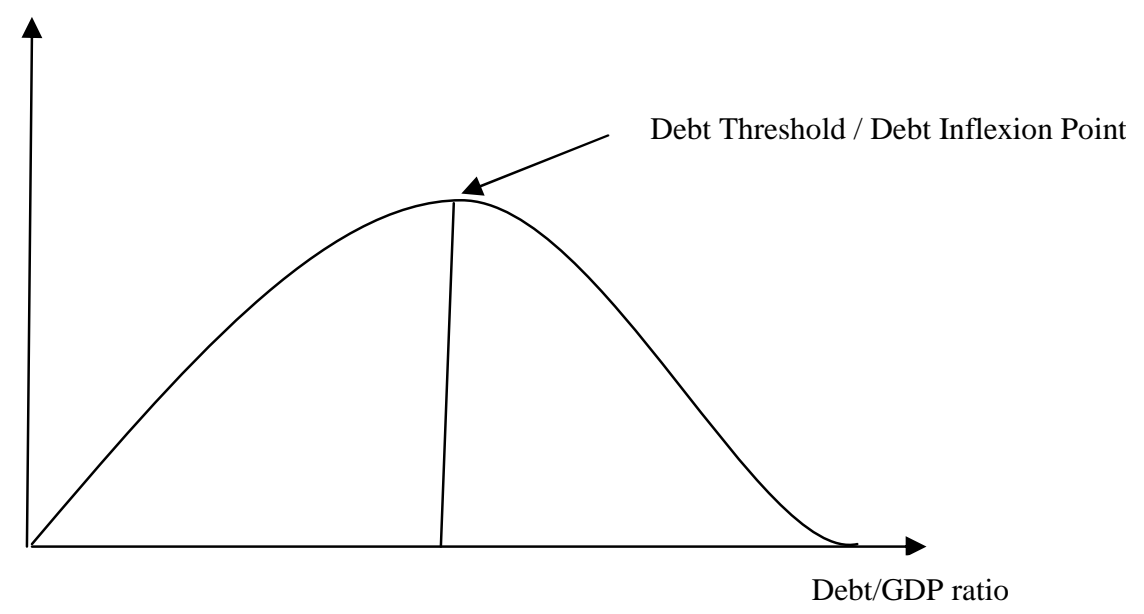

Empirical studies finding the optimal level of debt threshold are too many, however special attention have been received by only few studies. Reinhart and Rogoff (2010), a pioneering study on this topic, and Herndon et. al. (2013) figured out that the optimum debt-threshold is $90 \%$ of gross domestic product. For Caner et. al. (2010), this value was77\%, 55-56\% for Greenidge et. al. (2012), 61\% for Wright and Grenade (2014), 35-40\% for Pattillo et. al. (2002), 40-50\% for Mupunga and Roux (2015), 61\% for Mukherjee (2012), and 50-60\% for Munir et. al. (2016). Since major portion of twin deficits in Pakistan is covered through external finances, therefore the issue of finding the debt-inflexion point is more crucial for Pakistan as it has trapped our economy in the vicious cycle of poverty in the form of high unemployment (Ahmad, 2011), capital deficiency in the form of low FDI (Gul, 2008), and twin deficits (Khan et. al. 2016). The debt-to-GDP ratio for Pakistan is summarized in Figure 2. 


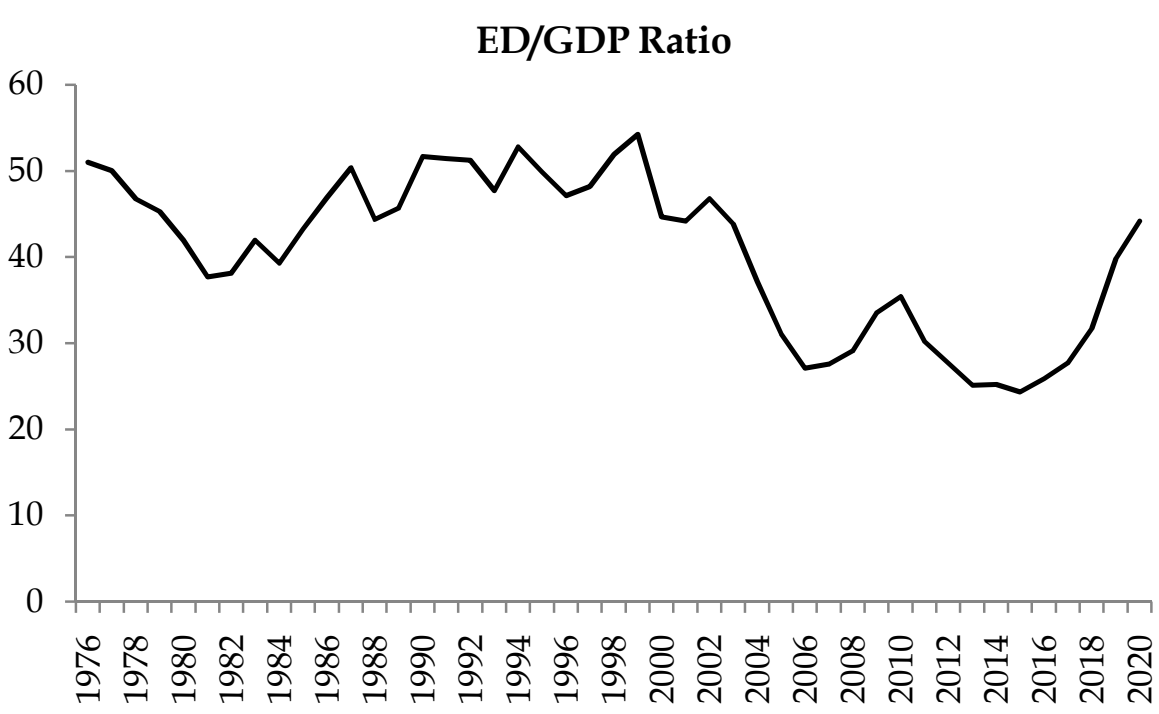

Figure 2: External Debt-to-GDP ratio (1976-2020)

We find so many studies highlighting the causes and consequences of foreign debt, but up to the best of our knowledge we find no study that has determined the debt-tipping point for Pakistan. So keeping in view the latest debt profile and statistical data, this study aims to provide a benchmark for policy makers and explore this issue for Pakistan economy for framing accurate and effective debt management policies. For this purpose, this study is using the ARDL model which is structured within the framework of neo-classical growth model. This study also aims to present results-oriented recommendations in the context of debt accumulation which are essential to be known and followed for the growth of an economy.

\section{Literature Review}

With regard to the significance of external finances, voluminous literatures have tried to investigate the impact of debt on economic productivity. In most of these studies, we find that access to international donor agencies and increase in external finances have positive impact on economic growth (Jilenga et al., 2016). Similarly, we also find that foreign debt gives birth to debt overhang effect which not only disrupts the growth process but also pushes the indebted country into deep debt-trap (Minhaj-ud-Din, Azam \& Tariq, 2020). Following this notion, most of the scholars are of the view that debt overhang is effective beyond the debt threshold only. They believe that debt overhang does not exist below the debt inflexion point. Nguyen et. al. (2003) noted that debt overhang is effective beyond the debt-threshold (50\% of GDP) in most of the least developed countries. However, this value was calculated as $100-105 \%$ of exports when external debt was expressed with the ratio of debt-to-exports. Cordella et. al. (2010) also tried to figure out this value for 80 developing countries. They found that debt overhang is effective for countries having a debt-threshold of 15-30\% of GDP. Debt overhang was found irrelevant for countries having debt-to-GDP ratio of above $70-80 \%$.Similarly, Reinhart and Rogoff 
(2010) found that this value is $90 \%$ of GDP for 44 developing countries. Greenidge et. al. (2012) used fixed effect model for exploring the effectiveness of debt overhang effect beyond the debt threshold in 12 CARIMON countries. They also confirmed that debt overhang exists beyond the debt-tipping point which is $55-56 \%$ of GDP. Wright and Grenade (2014) found a common debt threshold of $61 \%$ for public debt in thirteen Caribbean economies.

Mupunga and Roux (2015) examined the theory of debt-Laffer curve by estimating this non-linear relationship for 24 sub-Saharan African countries. As a matter of comparison, they estimated a threshold level of $40-50 \%$ of GDP for Zimbabwe. For rest of 23 least income countries, this threshold was found 80-120\% of GDP. Chudik et. al. (2015) also tried to investigate the universal applicability of this phenomenon for 40 indebted countries. They concluded that country with huge debt burden can grow just as fast as its peers. However, this study failed to detect a common threshold for these economies. In contrast, Omotosho et. al. (2016) noted that accumulation of public debt leads to debt overhang effect beyond the debt inflexion point which is $73.7 \%$ of GDP. They also calculated this threshold for foreign debt and domestic debt which were $49.4 \%$ and $30.9 \%$ of GDP, respectively. Cai (2017) also found that public debt is inimical and curse for the economy above the debt threshold. For Baharumshah et. al. (2017) this ratio was 55\% of GDP.

Van (2018) followed the debt Laffer curve theory and applied the fixed-effect model to a data set of 10 Southeast Asian economies. This study confirmed the presence of inverted-U relationship between debt and growth. The calculated value of debt-threshold was $70.42 \%$ of GDP. Tran (2018) also emphasized on tracing the debt limit for fourteen non-Latin and Latin American countries. Findings confirmed that debt has positive repercussion on the economy of non-Latin American countries as their debts remained lower than the debt inflexion point (i.e. $40-55 \%$ of GDP). However, this impact was found inimical for most of the Latin American countries as the ratio of debt-to-GDP for these countries was 35\%. He advised the policy making department for taking strict actions against the debt flight through implementation of fiscal discipline.

Khanfir (2019) tried to examine this non-linear relationship for four developing countries. Debt overhang was found effective beyond the debt-threshold (42.8\% of GDP). He emphasized on fiscal consolidation and reducing the magnitude of public debt for enhancing the economic productivity. Zaghdoudi (2019) also examined this relationship for a pool data of 109 countries from middle income and low income categories. He also confirmed the effectiveness of debt overhang beyond the threshold level of $15.28 \%$.This threshold was $62-66 \%$ of GDP for Ndoricimpa (2020) who investigated this issue for 39African countries. The impact of public debt was found more sever for debt abundant countries as compared to low-debt countries and moderate-debt countries. High public debt was found detrimental to the economic growth of debt holding economies. Lio and Lyu (2020) failed to detect a universal threshold for a sample of 102 countries. However, they noted that debt is 
a double-edge sword which not only hampers the economic growth but also brings shocks to the monetary system. They also concluded that debt creates economic uncertainty which decreases the expected debt threshold. Minhaj-ud-Din, Azam \& Tariq (2020) concluded that excessive accumulation of external debt is inimical and curse for public investment and economic productivity. Bhatta and Mishra (2020) estimated that optimal debt should not exceed 33\% of GDP which is mandatory for accelerating the economic growth of Nepal. Table 1 represents a brief sketch of the empirical work held on this topic.

Table 1

Summary of the Empirical Literature

\begin{tabular}{|c|c|c|c|}
\hline Author (s) & Sample Periods & Methodology & Findings \\
\hline $\begin{array}{c}\text { Nguyen et al. } \\
(2003)\end{array}$ & $\begin{array}{c}55 \text { highly indebted countries } \\
1970-1999 \\
\end{array}$ & $\begin{array}{c}\text { FEM } \\
\text { System GMM }\end{array}$ & $\begin{array}{c}50 \% \text { of GDP } \\
100-105 \% \text { of exports }\end{array}$ \\
\hline $\begin{array}{l}\text { Cordella et al. } \\
\qquad(2010)\end{array}$ & $\begin{array}{c}\text { Eighty indebted poor } \\
\text { countries } \\
1970-2002\end{array}$ & $\begin{array}{c}\text { POLS } \\
\text { System GMM }\end{array}$ & $15-30 \%$ of GDP \\
\hline $\begin{array}{l}\text { Reinhart \& Rogoff } \\
(2010)\end{array}$ & $\begin{array}{c}44 \text { developing countries } \\
1790-2009 \\
\end{array}$ & Causality analysis & $90 \%$ of GDP \\
\hline $\begin{array}{l}\text { Greenidge et al. } \\
(2012)\end{array}$ & $\begin{array}{c}12 \text { CARICOM countries } \\
1990-2010\end{array}$ & Fixed effects model & $55-56 \%$ of GDP \\
\hline $\begin{array}{c}\text { Wright \& Grenade } \\
\text { (2014) }\end{array}$ & $\begin{array}{l}13 \text { Caribbean countries } \\
2002-2012\end{array}$ & $\begin{array}{l}\text { Panel dynamic least } \\
\text { square }\end{array}$ & $61 \%$ of GDP \\
\hline $\begin{array}{l}\text { Mupunga \& Roux } \\
\qquad(2015)\end{array}$ & $\begin{array}{l}24 \text { sub-Saharan African } \\
\text { countries } \\
1980-2012\end{array}$ & $\begin{array}{c}\text { Instrumental } \\
\text { variable approach }\end{array}$ & $\begin{array}{c}40-50 \% \text { of GDP for } \\
\text { Zimbabwe } \\
80-120 \% \text { for the remaining } \\
\text { least income countries }\end{array}$ \\
\hline $\begin{array}{l}\text { Chudik et al. } \\
\text { (2015) }\end{array}$ & $\begin{array}{c}40 \text { countries } \\
1965-2010 \\
\end{array}$ & ARDL & $\begin{array}{c}\text { No universal debt } \\
\text { threshold }\end{array}$ \\
\hline $\begin{array}{l}\text { Omotosho et al. } \\
\qquad(2016)\end{array}$ & $\begin{array}{c}\text { Nigeria } \\
2005-2015\end{array}$ & ARDL, GCT & $\begin{array}{l}\text { 73.7\% of GDP for public } \\
\text { debt, } 49.4 \% \text { of GDP for } \\
\text { external debt, and } 30.9 \% \text { of } \\
\text { GDP for domestic debt }\end{array}$ \\
\hline $\begin{array}{l}\text { Baharumshah et. } \\
\text { al. (2016) }\end{array}$ & $\begin{array}{l}\text { Malaysia } \\
1980-2016\end{array}$ & $\begin{array}{l}\text { Markov-switching } \\
\text { intercept } \\
\text { autoregressive } \\
\text { model }\end{array}$ & $55 \%$ of GDP \\
\hline $\begin{array}{l}\text { Tran } \\
(2018)\end{array}$ & $\begin{array}{l}14 \text { emerging economies } \\
1999-2016\end{array}$ & $\begin{array}{l}\text { Panel threshold } \\
\text { model(PTM) }\end{array}$ & $\begin{array}{l}\text { 35\% of GDP for Latin } \\
\text { American countries, while } \\
\text { 40-55\% of GDP for non- } \\
\text { Latin American economies }\end{array}$ \\
\hline $\begin{array}{l}\text { Khanfir } \\
\text { (2019) }\end{array}$ & $\begin{array}{l}4 \text { north African countries } \\
\text { 2003-2012 }\end{array}$ & PTM & $42.89 \%$ of GDP \\
\hline $\begin{array}{l}\text { Zaghdoudi } \\
\text { (2019) }\end{array}$ & $\begin{array}{l}109 \text { middle and low income } \\
\text { countries } \\
2002-2016\end{array}$ & Dynamic PTM & $15.28 \%$ of GDP \\
\hline $\begin{array}{l}\text { Ndoricimpa } \\
\text { (2020) }\end{array}$ & $\begin{array}{l}39 \text { African countries } \\
1980-2012\end{array}$ & PTM & $62-66 \%$ of GDP \\
\hline $\begin{array}{c}\text { Lio \& Lyu } \\
(2020) \\
\end{array}$ & $\begin{array}{c}102 \text { countries } \\
1980-2016 \\
\end{array}$ & Fixed effects model & $\begin{array}{c}\text { No universal debt } \\
\text { threshold }\end{array}$ \\
\hline $\begin{array}{l}\text { Bhatta \& Mishra } \\
(2020) \\
\end{array}$ & $\begin{array}{c}\text { Nepal } \\
1976-2019 \\
\end{array}$ & ARDL & $33 \%$ of GDP \\
\hline
\end{tabular}

Source: Author's compilation 


\section{Specification of the Model and Data Source}

This study is using the augmented neo-classical growth model by incorporating the debt overhang indicator in the Solow Growth model used by Minhaj-ud-Din, Azam \& Tariq (2020). External debt as \% ofGDPis theproxy variable representing the debt-overhang effect of the foreign debt.In order to determine the debt inflexion point and examine the effectiveness of debt overhang effect, this study is using the following ARDL model.Description of variables and data source is presented in Table 2 .

$$
\begin{aligned}
& \Delta g p c_{t}=\delta_{0}+\sum_{i=1}^{n} \delta_{1} \Delta g p c_{t-1}+\sum_{i=0}^{n} \delta_{2} \Delta e d_{t-1}+\sum_{i=0}^{n} \delta_{3} \Delta e d^{2}{ }_{t-1}+ \\
& \sum_{i=0}^{n} \delta_{4} \Delta d s p_{t-1}+\sum_{i=0}^{n} \delta_{5} \Delta f d i_{t-1}+\sum_{i=0}^{n} \delta_{6} \Delta e r_{t-1}+\sum_{i=0}^{n} \delta_{7} \Delta g f c f_{t-1}+ \\
& \sum_{i=0}^{n} \delta_{8} \Delta h k_{t-1}+\sum_{i=0}^{n} \delta_{9} \Delta i n f_{t-1}+\sum_{i=0}^{n} \delta_{10} \Delta l f_{t-1}+\sum_{i=0}^{n} \delta_{11} \Delta f r_{t-1}+\gamma_{1} g p c_{t-1}+ \\
& \gamma 2 e d t-1+\gamma 3 e d 2 t-1+\gamma 4 d s p t-1+\gamma 5 \text { fdit }-1+\gamma 6 e r t-1+\gamma 7 g f c f t-1+\gamma 8 h k t-1+ \\
& \gamma \text { inft }-1+\gamma 10 / f t-1+\gamma 11 f r t-1+\epsilon j \text {. }
\end{aligned}
$$

\begin{tabular}{|c|c|c|c|c|}
\hline Variable & Symbol & Definition / Unit & Source & $\begin{array}{c}\text { Expected } \\
\text { Sign }\end{array}$ \\
\hline Gross domestic product & gdp & GDP per capita & WDI (2021) & + \\
\hline External debt & ed & $(\mathrm{ed} / \mathrm{gdp})^{*} 100$ & WDI (2021) & - \\
\hline Debt service payment & dsp & $(\mathrm{dsp} / \mathrm{X})^{* 100}$ & WDI (2021) & - \\
\hline Foreign direct investment & fdi & $(\mathrm{fdi} / \mathrm{gdp}) * 100$ & WDI (2021) & + \\
\hline Exchange rate & er & RS $/ \$$ & SBP (2021) & + \\
\hline Gross fixed capital formation & gfcf & $(\operatorname{gfcf} / \mathrm{gdp})^{*} 100$ & WDI (2021) & + \\
\hline Human capital & hk & Primary school enrollment & WDI (2021) & + \\
\hline Inflation & inf & CPI & WDI (2021) & - \\
\hline Labor force & If & $15<$ Population $>64$ & WDI (2021) & + \\
\hline Foreign reserves & $\mathrm{fr}$ & $(\mathrm{fr} / \mathrm{gdp})^{*} 100$ & WDI (2021) & + \\
\hline
\end{tabular}

Table 2

Description of variables and data sources (gdp is dependant variable)

\section{Justification of Variables}

GDP per capita is a growth detecting variable used by researchers inmost of the growth models. Foreign debt, as percent of gross domestic product, is used to determine the presence of debt overhang effect, whereas debt servicing, as percent of gross domestic product, is used to determine the presence of debt crowding out effect. Countries with higher ratios of these variables are expected to experience the coexistence of these affects (Minhaj-ud-Din, Azam \& Tariq, 2020). ED 2 is added to find the efficacy of debt overhang effect in the context of debt threshold. FDI is an indicator representing the level of investment which helps in stimulating the growth process of an economy. Stability of the local currency also plays an effective role in making the financial sector progressive and helps in enhancing the repayment ability of the debtor country (Ndbuisi, 2017).

GFCF also plays a substantial rolein stimulating the economic growth because it is the representative of capital which measures the increase in fixed 
assets/capital during an accounting period (Sen et al., 2017).Human capital is a key component of growth model representing the literacy rate, and reflected by the primary school enrolment (Kharusi \& Ada, 2018).Inflation rate measures the stability of an economy. Higher inflation causes the exchange rate to grow and declines the marginal efficiency of capital (Marshal \& Solomon, 2017). It also increases the nominal value of foreign debt and disrupts the growth process(Cordella et al., 2010).Labor force is also added in this model as it represents the participation ratio of specific population in the production process (Senadza et al., 2017). Increase in foreign reserves, on one side, causes the level of domestic investment to rise and accelerates the growth process, and, on other side, enhances the repayment abilities of the government(Fukuda \& Kon, 2010).

\section{Estimation Procedure}

The primary intention of this research is to investigate the non-linear relationship between debt and growth and determine the debt-inflexion point. It also intends to investigate whether the debt overhang is effective beyond the debtthreshold or not. For this purpose, the debt-threshold will be determined by adopting the following estimation procedure:

Step 1: Finding stationarity of data by using ADF and PP tests of stationarity.

Step 2: If data were found stationary, then we will use theF-bound test for confirming the existence of long-run association among the variabl eslisted in equation 1. In the presence of long-run co integration, the long-run coefficients will be estimated by using the following ARDL model.

$$
\begin{array}{r}
\Delta g d p_{t}=\delta_{0}+\sum_{i=1}^{n} \delta_{1} \Delta g d p_{t-1}+\sum_{i=0}^{n} \delta_{2} \Delta e d_{t-1}+\sum_{i=0}^{n} \delta_{3} \Delta e d_{t-1}^{2}+ \\
\sum_{i=0}^{n} \delta_{4} \Delta d s p_{t-1}+\sum_{i=0}^{n} \delta_{5} \Delta f d i_{t-1}+\sum_{i=0}^{n} \delta_{6} \Delta e r_{t-1}+\sum_{i=0}^{n} \delta_{7} \Delta g f c f_{t-1}+ \\
\sum_{i=0}^{n} \delta_{8} \Delta h k_{t-1}+\sum_{i=0}^{n} \delta_{9} \Delta i n f_{t-1}+\sum_{i=0}^{n} \delta_{10} \Delta l f_{t-1}+\sum_{i=0}^{n} \delta_{11} \Delta f r_{t-1}+\mu_{j} \ldots \ldots
\end{array}
$$

Steps 3: Estimating the short run parameters of the model by transformingthe ARDL model into the following ECM model:

$$
\begin{aligned}
& \Delta g d p_{t}=\rho_{0}+\sum_{i=1}^{n} \rho_{1} \Delta g d p_{t-1}+\sum_{i=0}^{n} \rho_{2} \Delta e d_{t-1}+\sum_{i=0}^{n} \rho_{3} \Delta d s p_{t-1}+ \\
& \sum_{i=0}^{n} \rho_{4} \Delta f d i_{t-1}+\sum_{i=0}^{n} \rho_{5} \Delta e r_{t-1}+\sum_{i=0}^{n} \rho_{6} \Delta g f c f_{t-1}+\sum_{i=0}^{n} \rho_{7} \Delta h k_{t-1}+ \\
& \sum_{i=0}^{n} \rho_{8} \Delta i n f_{t-1}+\sum_{i=0}^{n} \rho_{9} \Delta l f_{t-1}+\sum_{i=0}^{n} \rho_{10} \Delta f r_{t-1}+\zeta E C M_{t-1}+\varepsilon_{t}
\end{aligned}
$$

Step 4: Using adequate diagnostic / stability tests.

Step 5: Estimating the optimum level of debt-threshold by using the quadratic bivariate model based on the long-run coefficients of the ARDL model listed in Table 6 (Bhatta \& Mishra, 2020). Mathematically:

$$
\frac{d}{d(e d)}(g d p)=\text { Coefficent of ed } * \text { ed }- \text { Coefficient of } e d^{2} * e d^{2}=0
$$




\section{Empirical Results}

The empirical results of the steps mentioned above are listed in the following sub-sections.

\section{Stationarity}

Table 3 indicates that data of the model is stationary at level or at first difference. So we have to move further and use the F-bound test.

Table 3

Stationarity (ADF test\& PP test)

\begin{tabular}{|c|c|c|c|c|}
\hline \multirow{3}{*}{ Variable } & \multicolumn{2}{|l|}{ ADF Test } & \multicolumn{2}{|l|}{ PP Test } \\
\hline & With Intercept & $\begin{array}{l}\text { With Intercept } \\
\text { and Trend }\end{array}$ & With Intercept & $\begin{array}{l}\text { With Intercept } \\
\text { and Trend }\end{array}$ \\
\hline & $\begin{array}{l}\text { Statistics } \\
\text { \&Decision }\end{array}$ & $\begin{array}{l}\text { Statistics } \\
\text { \&Decision }\end{array}$ & $\begin{array}{l}\text { Statistics } \\
\text { \&Decision }\end{array}$ & $\begin{array}{l}\text { Statistics } \\
\text { \&Decision }\end{array}$ \\
\hline $\mathrm{dsp}_{\mathrm{t}}$ & $-9.278^{*}$ at $\mathrm{I}_{1}$ & $-9.391^{*}$ at $\mathrm{I}_{1}$ & $-4.572^{*}$ at $\mathrm{I}_{0}$ & $-4.523^{*}$ at $\mathrm{I}_{0}$ \\
\hline$e_{t}$ & $-6.879^{*}$ at $\mathrm{I}_{1}$ & $-6.778^{*}$ at $\mathrm{I}_{1}$ & $-6.879^{*}$ at $\mathrm{I}_{1}$ & $-6.778^{*}$ at $\mathrm{I}_{1}$ \\
\hline$e d_{t^{2}}$ & $-7.953^{*}$ at $\mathrm{I}_{1}$ & $-7.843^{*}$ at $\mathrm{I}_{1}$ & $-7.923^{*}$ at $\mathrm{I}_{1}$ & $-7.815^{*}$ at $\mathrm{I}_{1}$ \\
\hline $\mathrm{er}_{\mathrm{t}}$ & $-3.645^{*}$ at $\mathrm{I}_{1}$ & $-4.444^{*}$ at $\mathrm{I}_{1}$ & $-9.278^{*}$ at $\mathrm{I}_{1}$ & $-9.833^{*}$ at $\mathrm{I}_{1}$ \\
\hline $\mathrm{fdi}_{\mathrm{t}}$ & $-4.329^{*}$ at $\mathrm{I}_{1}$ & $-4.301^{*}$ at $\mathrm{I}_{1}$ & $-4.289^{*}$ at $\mathrm{I}_{1}$ & $-4.258^{*}$ at $\mathrm{I}_{1}$ \\
\hline$g d p_{t}$ & $-4.533^{*}$ at $\mathrm{I}_{0}$ & $-4.566^{*}$ at $\mathrm{I}_{0}$ & $-3.696^{*}$ at $\mathrm{I}_{1}$ & $-3.910^{* *}$ at $\mathrm{I}_{1}$ \\
\hline $\operatorname{gfcf}_{t}$ & $-3.242^{* *}$ at $\mathrm{I}_{0}$ & $-3.698^{* *}$ at $\mathrm{I}_{0}$ & $-3.241^{* *}$ at $\mathrm{I}_{0}$ & $-3.667^{* *}$ at $\mathrm{I}_{0}$ \\
\hline $\mathrm{hk}_{\mathrm{t}}$ & $-9.404^{*}$ at $I_{1}$ & $-10.133^{*}$ at $I_{1}$ & $-9.431^{*}$ at $I_{1}$ & $-10.63^{*}$ at $\mathrm{I}_{1}$ \\
\hline $\inf _{t}$ & $-8.614^{*}$ at $\mathrm{I}_{1}$ & $-8.839^{*}$ at $\mathrm{I}_{1}$ & $-8.184^{* *}$ at $\mathrm{I}_{1}$ & $-8.825^{*}$ at $\mathrm{I}_{1}$ \\
\hline $\mathrm{fr}_{\mathrm{t}}$ & $-7.566^{*}$ at $\mathrm{I}_{1}$ & $-7.463^{*}$ at $\mathrm{I}_{1}$ & $-7.675^{*}$ at $\mathrm{I}_{1}$ & $-7.564^{*}$ at $\mathrm{I}_{1}$ \\
\hline $\operatorname{lf}_{\mathrm{t}}$ & $-3.196^{* *}$ at $I_{1}$ & $-4.913^{*}$ at $\mathrm{I}_{1}$ & $-7.694^{*}$ at $I_{1}$ & $-9.061^{*}$ at $\mathrm{I}_{1}$ \\
\hline
\end{tabular}

\section{F-Bound Test}

The resulted value of F-Bound test (depicted in Table 5) indicates the existence of long-run co integration among the variables. So we have to move further for estimating the long-run coefficients of the ARDL model.

Table 5

F-Bound Test

\begin{tabular}{ccc}
\hline \multirow{2}{*}{ F-statistic } & \multicolumn{2}{c}{$\mathbf{9 . 5 1 4}$} \\
\cline { 2 - 3 } & lower bound & upper bound \\
\hline 10 percent & 1.82 & 2.95 \\
\hline 5 percent & 2.05 & 3.26 \\
\hline 2.5 percent & 2.27 & 3.51 \\
\hline 1 percent & 2.49 & 3.89 \\
\hline
\end{tabular}




\section{Long-Run Analysis}

The long run estimates of the ARDL model (depicted in Table 6) indicate that; first, "ed", "dsp", "gfcf", "lf", and "fr'are significant at one percent, second, "fdi" and "er" are significant at five percent, and third, "hk" and "inf" are significant at ten percent level of significance.

Table 6

Long-Run Analysis

\begin{tabular}{cccc}
\hline Variable & Coefficient & Statistics & p-Value \\
\hline $\mathrm{ed}_{\mathrm{t}}$ & $-0.264^{*}$ & -0.245 & 0.009 \\
\hline $\mathrm{ed}_{\mathrm{t}}{ }^{2}$ & $-0.005^{*}$ & -3.039 & 0.008 \\
\hline $\mathrm{dsp}_{\mathrm{t}}$ & $-0.149^{*}$ & -0.786 & 0.008 \\
\hline $\mathrm{fdi}_{\mathrm{t}}$ & $1.097^{* *}$ & 2.859 & 0.012 \\
\hline $\mathrm{er}_{\mathrm{t}}$ & $0.107^{* *}$ & 2.608 & 0.020 \\
\hline $\mathrm{gfcf}_{\mathrm{t}}$ & $0.691^{*}$ & 4.572 & 0.000 \\
\hline $\mathrm{hk}_{\mathrm{t}}$ & $0.157^{* * *}$ & 1.975 & 0.068 \\
\hline $\mathrm{inf}_{\mathrm{t}}$ & $-0.122^{* * *}$ & -2.087 & 0.055 \\
\hline $\mathrm{lf}_{\mathrm{t}}$ & $1.937^{*}$ & 4.791 & 0.000 \\
\hline $\mathrm{fr}_{\mathrm{t}}$ & $1.264^{*}$ & 3.978 & 0.001 \\
\hline $\mathrm{C}$ & -77.546 & -2.509 & 0.025 \\
\hline
\end{tabular}

${ }^{* * *}$, and ${ }^{* * *}$ denotes the significance of variable at $1 \%, 5 \%$ and $10 \%$ level of significance

The coefficients of "ed" and "dsp" indicate the co-existence of debt-overhang and debt-crowding out effects as their coefficients are negative and statistically significant. It means that growth in external financial liabilities (foreign debt and debt servicing) is inimical and curse for growth and prosperity. The coefficients of these variables also indicate that debt overhang effect is more inimical than the debt crowding out effect.One percent increase in "ed" and "dsp" is causing approximately 0.26 and 0.14 percent decrease in GDP per capita. These findings are in line with the findings ofShabbir (2013), Shittu et. al. (2018), Shkolnyk and Koilo (2018), and Minhaj-ud-Din, Azam \& Tariq (2020) who also portrayed similar kind of results.

The coefficients of the remaining variables also got their expected values. This study finds that "fdi", "gfcf", "hk", "lf" and " $\mathrm{fr}$ " significantly determine the economic growth in Pakistan. One percent increase in the value of these variables is associated with approximately 1.69, 0.69, 0.15, 1.93 and 1.26 percent increase in GDP per capita, respectively. These estimates are also in line with most of the studies held on this topic(Shabbir, 2013;Zafar et al., 2015;Fandamu \& Phiri 2017;Senadza et al., 2017;Ndubuisi 2017;Minhaj-ud-Din, Azam \& Tariq, 2020).

Similarly, the coefficient of exchange rate "er" indicates that $1 \%$ growth in "er" iscausing the economic productivity to grow by 0.10 percent. These outcomes are consistent with the findings ofShabbir (2013), and Ndubuisi (2017). The last variable, i.e. inflation rate, also got its expected signed as discussed earlier. Increase in inflation rate is also considered as a curse for growth in economic productivity. 
These results support the findings of most of the studies held on this topic (Cordella et al., 2010;Kharusi \& Ada, 2018;Ciftcioglu \& Sokhanvar, 2018;Nor-Eddine \& Chkiriba, 2019;Minhaj-ud-Din, Azam \& Tariq, 2020)

\section{Short-run Analysis}

The estimates of ECM model (depicted in table 7) indicate that 54 percent of the disequilibrium will be adjusted within the first year, and will need approximately one more year to converge back to the long run equilibrium.

Table 7

Short Run Analysis

\begin{tabular}{cccc}
\hline Variables & Coefficients & t-Statistics & p-Values \\
\hline ecm $_{\mathrm{t}}(-1)$ & -0.544 & -7.261 & 0.000 \\
\hline $\mathrm{ed}_{\mathrm{t}}(-1)$ & $-0.205^{*}$ & -5.045 & 0.000 \\
\hline $\mathrm{dsp}_{\mathrm{t}}(-1)$ & -0.019 & -0.418 & 0.678 \\
\hline $\mathrm{fdi}_{\mathrm{t}}(-1)$ & 0.300 & 0.901 & 0.374 \\
\hline $\mathrm{er}_{\mathrm{t}}(-1)$ & $0.125^{*}$ & 2.880 & 0.007 \\
\hline $\mathrm{gfcf}_{\mathrm{t}}(-1)$ & $0.564^{*}$ & 4.222 & 0.000 \\
\hline $\mathrm{hk}_{\mathrm{t}}(-1)$ & $0.135^{* *}$ & 2.192 & 0.036 \\
\hline $\inf _{\mathrm{t}}(-1)$ & -0.048 & -1.169 & 0.251 \\
\hline $\mathrm{lf}_{\mathrm{t}}(-1)$ & $1.447^{*}$ & 5.182 & 0.000 \\
\hline $\mathrm{fr}_{\mathrm{t}}(-1)$ & $1.399^{*}$ & 5.029 & 0.000 \\
\hline $\mathrm{C}$ & -0.441 & -2.416 & 0.022 \\
\hline
\end{tabular}

${ }^{*} \&{ }^{* *}$ indicate the significance of variables at $1 \%$ and $5 \%$ level of significance

Summary of the Diagnostic Tests

Table 8

Diagnostic Tests

\begin{tabular}{|c|c|c|c|}
\hline Test & Estimates & $\begin{array}{l}\text { F-Statistics }(\mathrm{P}- \\
\text { value })\end{array}$ & Interpretation \\
\hline DW & 2.3148 & ---- & No issue of auto correlation \\
\hline BPG & ----- & $0.8616(0.641)$ & No issue of serial correlation \\
\hline LM & ----- & $1.827(0.606)$ & No issue of heteroscedasticity \\
\hline $\mathrm{JB}$ & $2.592(0.273)$ & ----- & Residuals are normally distributed \\
\hline $\mathrm{R}^{2}$ & 0.93 & ----- & $\begin{array}{l}\text { 93\% of the data fit the regression } \\
\text { model }\end{array}$ \\
\hline$k=$ & 0.90 & ----- & $\begin{array}{l}90 \% \text { of the data fit the regression } \\
\text { model }\end{array}$ \\
\hline
\end{tabular}

\section{Estimation of Debt-Threshold}

The optimum level of debt-threshold can be determined by putting the coefficients of "ed" and "ed2" from Table 6into equation 4. Mathematically: 


$$
\frac{d(g d p)}{d(e d)}=0.264 * e d-0.005 * e d^{2}=0
$$

Apply the derivative andmake it equal to zero.

$$
\begin{gathered}
0.264-2(0.005) * e d=0 \\
0.264-0.01 * e d=0 \\
0.264=0.01 * e d \\
e d=0.264 / 0.01
\end{gathered}
$$$$
\text { Debt threshold }=26.4
$$

It means that debt overhang is effective above the optimum level of foreign debt which is $26.4 \%$ of gross domestic product. It also signifies that Pakistan is experiencing the debt-overhang effect throughout the period under analysis, as the ratio of external debt to GDP has always remained beyond this level of threshold. Specifically, if we compare the last four years data of Pakistan related to the concerned parameters, then the resulted negative impact of debt flight can be seen in the form of debt overhang effect which has caused a huge decline in GDP growth from $5.7 \%$ in 2017 to $-0.39 \%$ in 2020 (WDI, 2021). Since we don't find any study that has explicitly examined the debt threshold for Pakistan, that's why we are unable to make any comparison in this regard. However, our results are consistent with the conclusions made by most of the studies held globally. Specifically, our findings are consistent with the conclusions made by Pattillo et. al. (2002), Nguyen et. al. (2003), Mupunga and Roux (2015), Baharumshah et. al. (2016), Tran (2018), Khanfir (2019), Zaghdoudi (2019), and Bhatta and Mishra (2020) who found that debt accumulation should be made at moderate level of GDP. However, our findings are different from that of Chudik et. al. (2015) and Lio and Lye (2020) who were unable to detect debt threshold in their studies.

\section{Conclusion and Policy Recommendations}

The primary purpose of this article was to determine the effectiveness of debt overhang effect above the debt-inflexion point, as increase in burden of debt is considered detrimental for economic growth. Solow Growth model was used to fix the debt tipping point. ARDL and ECM models were used to complete the long run and short run analysis. Different sort of diagnostic tests were also conducted. Sample period was ranging from 1976-2020. Finding revealed that debt overhang is effective above the optimal level of foreign debt which is $26.4 \%$ of gross domestic product. Findings also revealed that Pakistan is experiencing the debt-overhang effect since 1976 as the ratio of external debt-to-GDP has remained over and above the optimal level of debt across the sample. Since no government can avoid external borrowing completely, therefore this study suggests that government borrowing should be restricted to the estimated optimum level of foreign debt, otherwise it will lead to 
disrupt the whole economy. Similarly, efforts should also be made for downsizing the debt burden by utilizing the non-debt sources of finances like grants and revenues and that effective debt-management policies should be formulated for maintaining an optimal level of economic growth. 


\section{References}

Apere, T. (2014). The impact of public debt on private investment in Nigeria: Evidence from a nonlinear model. International Journal of Research in Social Sciences, 4(2), 130-138.

Baharumshah, A. Z., Soon, S. V., \& Lau, E. (2017). Fiscal Sustainability in an Emerging Market Economy: When does Public Debt Turn Bad? Journal of Policy Modeling 39(1), 99-113.

Bhatta, G. P., \& Mishra, A. (2020). Estimating Optimum Growth-Maximizing Public Debt Threshold for Nepal. NRB Economic Review, 32(2), 1-28.

Cai, Y. (2017). Nonlinear Analysis of Economic Growth, Public Debt and Policy Tools. Asian Economic and Financial Review 7(1), 99-108.

Caner, M., Grennes, T., \& Koehler-Geib, F. (2010). Finding the Tipping Point when Sovereign Debt Turns Bad. Paper Submitted to Conference Volume: World Bank Conference on Debt Management, 1-17.

Chudik, A., Mohaddes, K., Pesaran, M. H., \& Raissi, M. (2017). Is there a debtthreshold effect on output growth? Review of Economics and Statistics, 99(1), 135-150.

Ciftcioglu, S., \& Sokhanvar, A. (2018). External debt-economic growth nexus in selected CEE countries. Romanian Journal of Economic Forecasting, 21(4), 85-100

Cordella, T., Ricci, L. A., \& Ruiz-Arranz, M. (2010). Debt overhang or debt irrelevance? IMF Staff Papers, 57(1), 1-24.

Fandamu, L. D. S. K. H., \& Phiri, C. (2017). The Impact of External Debt on Zambia's Economic Growth: An ARDL Approach. Journal of Economics and Sustainable Development, 8(8), 55-68

Fukuda, S.-i., \& Kon, Y. (2010). Macroeconomic impact of foreign exchange reserve accumulation: Theory and international evidence. ADBI Working Paper 197.

Greenidge, K., Craigwell, V., Thomas, C., \& Drakes, L. (2012). Threshold Effects of Sovereign Debt: Evidence from the Caribbean. IMF Working Paper 157, 1-22.

Herndon, T., Ash, M., \& Pollin, R. (2013). Does High Public Debt Consistently Stifle Economic Growth?: A Critique of Rienhart and Rogoff. Politcal Economy Reseach Institute, University of Massachusetts Amherst, 322, 1-25.

Jilenga, M. T., Xu, H., \& Gondje-Dacka, I.M. (2016). The impact of external debt and foreign direct investment on economic growth, empirical evidence from Tanzania. International Journal of Financial Research, 7(2), 154-165. 
Khanfir, W. (2019). Threshold effect of public debt on economic growth: An empirical investigation for selected North African countries. Economic Alternatives, 3, 429-436.

Kharusi, S. A., \& Ada, M. S. (2018). External debt and economic growth: The case of emerging economy. Journal of economic integration, 33(1), 1141-1157.

Liu, Z., \& Lyu, J. (2021). Public debt and economic growth: threshold effect and its influence factors. Applied Economics Letters, 28(3), 208-212.

Mabula, S., \& Mutasa, F. (2019). The Effect of Public Debt on Private Investment in Tanzania. African Journal of Economic Review, 7(1), 109-135.

Marshal, I., \& Solomon, I. D. (2017). Nigeria economy and the politics of recession: a critique. Journal of Advances in Economics and Finance, 2(4), 258-267.

Minhaj-ud-Din, Khan, M. A., \& Tariq, M. (2020). External debt - blessing or curse: Empirical evidence from Pakistan. International Journal of Economics and Financial Issues, 10(4), 235-246.

Minhaj-ud-Din, Khan, M. A., \& Tariq, M. (2020). External Debt and Public Investment: A Case Study of Pakistan. Journal of Management Sciences, 14(2), 118-117.

Munir, Q., Nasir, W. A., \& Ching, K. S. (2016). Determining the Optimal Level of External Debt and Debt-Growth Relation: A Case Study of Malaysia. Proceedings of the Annual Vietnam Academic Research Conference on Global Business, Economics, Finance and Social Sciences (AP16Vietnam Conference) 7(9), 1-12.

Mupunga, N. \& Roux, P. 1. (2015). Estimating the Optimal Growth-Maximising Public Debt Threshold for Zimbabwe. Southern African Business Review 19(3), 102-128

Ndoricimpa, A. (2020). Threshold effects of public debt on economic growth in Africa: a new evidence. Journal of Economics and Development, 22(2), 187-207

Ndubuisi, P. (2017). Analysis of the impact of external debt on economic growth in an Emerging Economy: Evidence from Nigeria. African Research Review, 11(4), 156-173

Nguyen, T. Q., Clements, M. B. J., \& Bhattacharya, M. R. (2003). External debt, public investment, and growth in low-income countries: IMF Working Paper $\mathrm{WP} / 03 / 249$. 
Nor-Eddine, O., \& Chkiriba, D. (2019). External public debt and economic growth in Morocco: assessment and impacts. Global Journal of Management And Business Research, 19(1), 39-48.

Nwankwo, O. (2014). Effect of capital structure of Nigeria firms on economic growth. Mediterranean Journal of Social Sciences, 5(1), 515-515.

Ogunmuyiwa, M. (2011). Does external debt promote economic growth in Nigeria. Current Research Journal of Economic Theory, 3(1), 29-35.

Omotosho, B. S., Bawa, S., \& Doguwa, S. I. (2016). Determining the optimal public debt threshold for Nigeria. CBN Journal of Applied Statistics, 7(2), 1-25.

Pattillo, C. A., Poirson, H., \& Ricci., L. A. (2002). External Debt and Growth. International Monetary Fund. 01-47.

Reinhart, C. M., \& Rogoff, K. S. (2010). Growth in a Time of Debt. American Economic Review 100, 573-578.

Sen, S., Kasibhatla, K. M., \& Stewart, D. B. (2007). Debt overhang and economic growth-the Asian and the Latin American experiences. Economic Systems, 31(1), 3-11.

Senadza, B., Fiagbe, K., \& Quartey, P. (2017). The effect of external debt on economic growth in Sub-Saharan Africa. International Journal of Business and Economic Sciences Applied Research (IJBESAR), 11(1), 1-14.

Shabbir, S. (2013). Does external debt affect economic growth: Evidence from developing countries. SBP Working Paper Series No. 63 (1-20): State Bank of Pakistan, Research Department.

Shittu, W. O., Hassan, S., \& Nawaz, M. A. (2018). The nexus between external debt, corruption and economic growth: evidence from five SSA countries. African Journal of Economic and Management Studies, 9(3), 319-334.

Shkolnyk, I., \& Koilo, V. (2018). The relationship between external debt and economic growth: Empirical evidence from Ukraine and other emerging economies. Investment Management and Financial Innovations, 15(1), 387-400

State Bank of Pakistan (2021). Handbook of statistics on Pakistan economy (various issues).

Tran, N. (2018). Debt threshold for fiscal sustainability assessment in emerging economies. Journal of Policy Modeling, 40(2), 375-394.

Van, T. H. \& Hoang, V. C. (2018). Determine the External Debt Threshold of the Southeast Asian Countries: Analysis Using Laffer Curve? Ekonomika Regiona [Economy of Region], 14(3), 1038-1045. 
World Development Indicators (2021). The World Bank.

Wright, A., \& Grenade, K. (2014). Determining optimal public debt and debt-growth dynamics in the Caribbean. Research in applied Economics, 6(2), 87-115.

Zafar, M., Sabri, P. S. U., Ilyas, M., \& Kousar, S. (2015). The impact of trade openness and external debt on economic growth: new evidence from south asia, east asia and middle east. Science International, 27(1), 509-516

Zaghdoudi, T. (2019). Threshold effect in the relationship between external debt and economic growth: A dynamic panel threshold specification. Journal of Quantitative Economics, 1-10. 